\title{
Specimens of the Pacific longnose chimaera Harriotta raleighana Goode \& Bean 1895 from the Mexican Pacific in scientific collections of Mexico and the world
}

\author{
Pedro Medina-Rosas ${ }^{1}$ \& Alma Raymundo-Huizar ${ }^{1}$ \\ ${ }^{1}$ Universidad de Guadalajara, Centro Universitario de la Costa, Jalisco, México \\ Corresponding author: Pedro Medina-Rosas (pedromedinarosas@gmail.com)
}

\begin{abstract}
Chimaeras are cartilaginous fish that live in waters more than $200 \mathrm{~m}$ deep. There are two species in the Rhinochimaeridae family, where only one, Harriotta raleighana, occurs in Mexican waters. It is considered a rare species for the country because of the number of observations and specimens collected in the Mexican Pacific, from Baja California to Colima, starting more than 100 years ago. This work integrates for the first time the published and unpublished information of this species for this region. Only seven specimens have been collected; they are deposited in different scientific collections of Mexico and the USA. Interestingly, none of these specimens were collected during surveys since all have been collected incidentally by fishermen. There is currently one specimen missing from a collection, a relevant issue due to its rareness. Samples must be deposited and preserved adequately for further studies about this rare and other deep-sea species, that improves the knowledge of the Mexican marine diversity.
\end{abstract}

Keywords: Harriotta raleighana; chimaera; rare species; archibenthic; abyssal; Mexican Pacific

\section{INTRODUCTION}

Chimaeras belong to the family Rhinochimaeridae, subclass Holocephali, class Chondrichthyes, which includes cartilaginous fish (Nelson et al. 2016). Given their appearance, they have been classified as marine monsters, where even the origin of the family name refers to the nose and monstrous appearance (rhinos and chimaera). Chimaeras are deep-sea fishes, with a depth range of 380-2600 m (Robertson \& Allen 2015), they have been observed or collected only a few times due to their habitat and behavior. This family includes eight species of three genera (Harriotta, Neoharriotta and Rhinochimaera). Genus Harriotta contains two species: H. haeckeli Karrer 1972 distributed in the northeastern Atlantic and the Pacific near New Zealand, and $H$. raleighana Goode \& Bean 1895 . The latter has been found in isolated sites of the Atlantic and the Pacific's temperate waters, both in the northern and southern hemispheres. However, there are isolated records in tropical seas (Ebert \& Stehmann 2013, Nelson et al. 2016, Weigmann 2016, Priede 2017). Their main difference is that $H$. haeckeli is smaller in body and eye sizes, its dorsal fin spine is significantly shorter than the height of the first dorsal fin and has a pale brown color with darker shading on its underside (Didier et al. 2012, Roberts et al. 2015).

Harriotta raleighana is known as Pacific longnose chimaera (Weigmann 2016), and it is registered as one of the 2763 species of fish in Mexican waters (Espinosa-Pérez 2014). Although chimaeras are in the group of cartilaginous fish with the least number of species in the country, only eight, represents $15 \%$ of the known species in the world for this group (Del MoralFlores et al. 2016a). There is a lack of commercial and economic interest precisely by their habitat and low number, and it has a conservation status of least concern to the International Union for Conservation of Nature (IUCN) Red List of Threatened Species (Del Moral-Flores et al. 2015, Dagit et al. 2016). Its reproductive biology has been recently described for the first time in a study in New Zealand, exemplifying its rarity. In this region, this species is relatively common (Finucci et al. 2017). There are still places on the planet where this and other chimaera species have been recently reported, such as Greenland (Møller et al. 2010), Yemen (Ali et al. 2009), and India (Suresh \& Raffi 2012). It has been rarely observed in Mexico, as it is explained below, there are a few collected specimens, although their findings have recently increased. 
Current data confirms that there is little scientific information on the biology and ecology of this chimaera species in Mexico due to the difficult access to its habitat for studies. Therefore, each observation record or specimens collected, even if they are sporadic and isolated, are relevant to increase the knowledge of its distribution and understand the structure of the population as well as its life history (Espinosa 2003, Dagit et al. 2016). Additionally, it is necessary to emphasize the importance that once a specimen has been collected and identified, it should be deposited in a scientific collection, which will support its adequate preservation and further studies (Espinosa 2003, De la Cruz-Agüero et al. 2012, Kemp 2015).

The purpose of this work is to update and integrate for the first time the information of the specimens of the Pacific longnose chimaera Harriotta raleighana collected in the Mexican Pacific, including unpublished records, that are deposited in scientific collections of scientific institutions of Mexico and other countries.

\section{MATERIALS AND METHODS}

Specialized literature and bibliography published were consulted and reviewed for Harriotta raleighana records on Mexican Pacific waters. Search for unpublished records of specimens deposited in collections was performed by consulting the species records and ichthyological collections (Del Moral-Flores et al. 2018) and online vertebrate's global databases from Mexican institutions and other countries, including the Ocean Biogeographic Information System (OBIS 2020), the Global Biodiversity Information Facility (GBIF 2020), the FishBase Project (Froese \& Pauly 2019), Fishnet2 (www.fishnet2.org), World Register of Marine Species (WoRMS 2020), VertNet (http:// vertnet.org), the Colección Nacional de Peces from the Instituto de Biología, Universidad Nacional Autónoma de México (http://www.ib.unam.mx/cnpe/), Global Biodiversity Information Network (REMIB, by its acronym in Spanish) of CONABIO (http://www. conabio.gob.mx/remib_ingles/doctos/remib_ing.html), as well as the Del Moral-Flores et al. (2016b) database. All accessed in January 2019 and confirmed in October 2020 for any changes.

Once scientific collections containing H. raleighana specimens were identified in Mexico, and other countries, mainly the USA, responsible or staff were contacted to obtain current information on the specimens' condition and images.

\section{RESULTS}

Specimens of Harriotta raleighana have been collected from Mexican waters for more than 100 years.
However, none of them has been captured by surveys or studies in deep waters. All of them have been encountered by anglers, mainly offshore, and using their traps or longlines. Specimens have been deposited in scientific collections of academic institutions from Mexico and the USA, but not all of them have been reported in scientific papers.

The first specimen was collected on April 22, 1911, in Baja California Sur, station $5685\left(25^{\circ} 42^{\prime} 45^{\prime \prime} \mathrm{N}\right.$, $113^{\circ} 38^{\prime} 30^{\prime \prime}$ ) (Fig. 1), as part of the Albatross vessel oceanographic expedition, at $1180 \mathrm{~m}$, and reported as $H$. curtissjamesi, described as new species by Townsend \& Nichols (1925), now a synonym of $H$. raleighana. The specimen was initially deposited in the Ichthyology Collection of the American Museum of Natural History but currently is located in the Smithsonian Institution (USNM 87552). The total length (TL) of the specimen is $15.2 \mathrm{~cm}$, and its sex was not reported in the original description (Townsend \& Nichols 1925). Due to its current state, after more than 100 years of preservation in the collections, the specimen is fragile and with some broken body parts (Fig. 2a).

In 1979, the second specimen (Fig. 2b) was collected off Tijuana, Baja California, $9 \mathrm{~km}$ away from the bank known as "60 miles" $\left(32^{\circ} 04\right.$ '15"N, $118^{\circ} 12^{\prime} 48^{\prime \prime} \mathrm{W}$ ) (Fig. 1). There is no depth record. Even though it is deposited in the Ichthyology section of the Natural History Museum of Los Angeles County (LACM 38360-1), it is not included in any report. The specimen's total length is $69.8 \mathrm{~cm}$ (Fig. 2b), its sex was not identified, and was collected by Dave Allen, from the Danny Boy boat, using a black cod trap, a deep-sea fish. A year before, using the same traps, four chimaera eggs were collected (they are in the same collection) by Dwight Chapin, from the RV Calafia, at 950 and 1050 $\mathrm{m}$ depth, in a zone close where the adult specimen was collected.

The first report for the Gulf of California was a female of $84 \mathrm{~cm}$ (TL) captured on March 24, 1982, 60 km off Mazatlán, Sinaloa (no coordinates) (Fig. 1). The specimen was collected (by-catch) between 300 and 700 m depth (Van der Heiden 1985). This specimen was originally deposited in the Reference Collection (1981-1) of the Unidad Mazatlán in the Instituto de Ciencias del Mar y Limnología of the Universidad Nacional Autónoma de México.

The most southern report for this species in Mexico was a specimen collected on June 1, 2006, $46 \mathrm{~km}$ off Manzanillo, Colima (no coordinates) (Fig. 1). Fishermen found it floating on the ocean surface. The specimen was documented under the incorrect name of Harriota raleighiana (note the missing $\mathrm{T}$ in the genus name and the extra $I$ in the species name, Castro- 


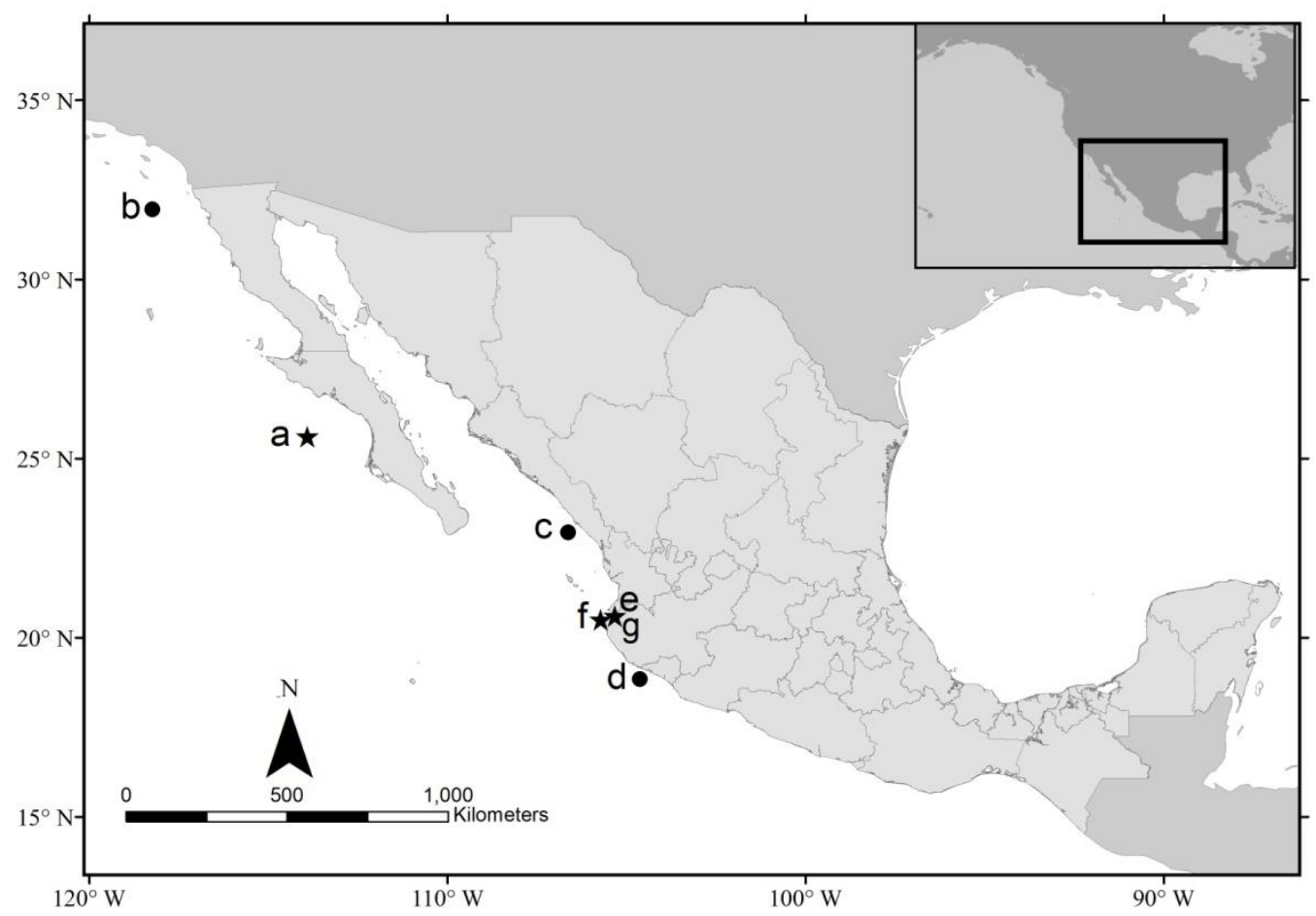

Figure 1. Map of Mexico with the collection sites of Harriotta raleighana specimens. Stars correspond to sites with coordinates, and spots correspond to the approximate location according to the source (no coordinates were provided). a) Townsend \& Nichols (1925), b) unpublished record, specimen deposited in the collection of the Ichthyology Section, Natural History Museum of Los Angeles County (LACM 38360-1), c) Van der Heiden (1985) d) Castro-Aguirre et al. (2007), e) Medina-Rosas \& Raymundo-Huizar (2014), f) Medina-Rosas \& Raymundo-Huizar (2019), g) Medina-Rosas \& Raymundo-Huizar (2020).

Aguirre et al. 2007). It is a female of $77.6 \mathrm{~cm}$ (TL), and it is deposited in the Colección Ictiológica of the Centro Interdisciplinario de Ciencias Marinas, Instituto Politécnico Nacional, in La Paz, Baja California Sur, México (CI 6369, Fig. 2c). Even though it is the report more austral for Mexico, this species has been reported in Central America's Pacific deep waters, such as Nicaragua, Costa Rica, and Panama (Angulo et al. 2014).

The last three specimens of this chimaera found in the Mexican Pacific have been curiously collected on the coast of Bahía de Banderas, Jalisco (Fig. 1), the only state in Mexico with more than one record for this species. The first specimen was collected in 2014 (Fig. 2d, Medina-Rosas \& Raymundo-Huizar 2014), the second one in 2018 (Fig. 2e, Medina-Rosas \& Raymundo-Huizar 2019), and the third one in 2020 (Fig. 2f, Medina-Rosas \& Raymundo-Huizar 2020). Contrary to the other specimens collected in the Mexican Pacific, these specimens were found dead close to the coastline, and were not collected from deep waters or offshore. Two specimens were floating on the sea surface, meters away from Caletas' beach, and the other one was trapped in a chinchorro, a fishnet used by local fishermen in shallow waters, close to the surface.

As part of the search results in online databases, there is a record for this species from the Museu de Ciències Naturals of Barcelona, Spain. After consulting with the institution's staff, it was confirmed that this record is incorrect. There is no specimen of this chimaera from Mexico or any other part of the world in that collection.

\section{DISCUSSION}

Due to the number of observations and specimens collected of Harriotta raleighana in more than a century, this chimaera could be considered as a rare species in Mexico. This chimaera was described in 1895, based on four specimens from the Atlantic, collected by the steamer Albatross (Goode \& Bean 1895). It was named after Sir Walter Raleigh, an English philosopher and explorer that lived in the $16^{\text {th }}$ century. A few years after the description, the Mexican Pacific's first specimen was collected in 1911, in another expedition of the Albatross. Even though the history of this chimaera's collected samples in this re- 


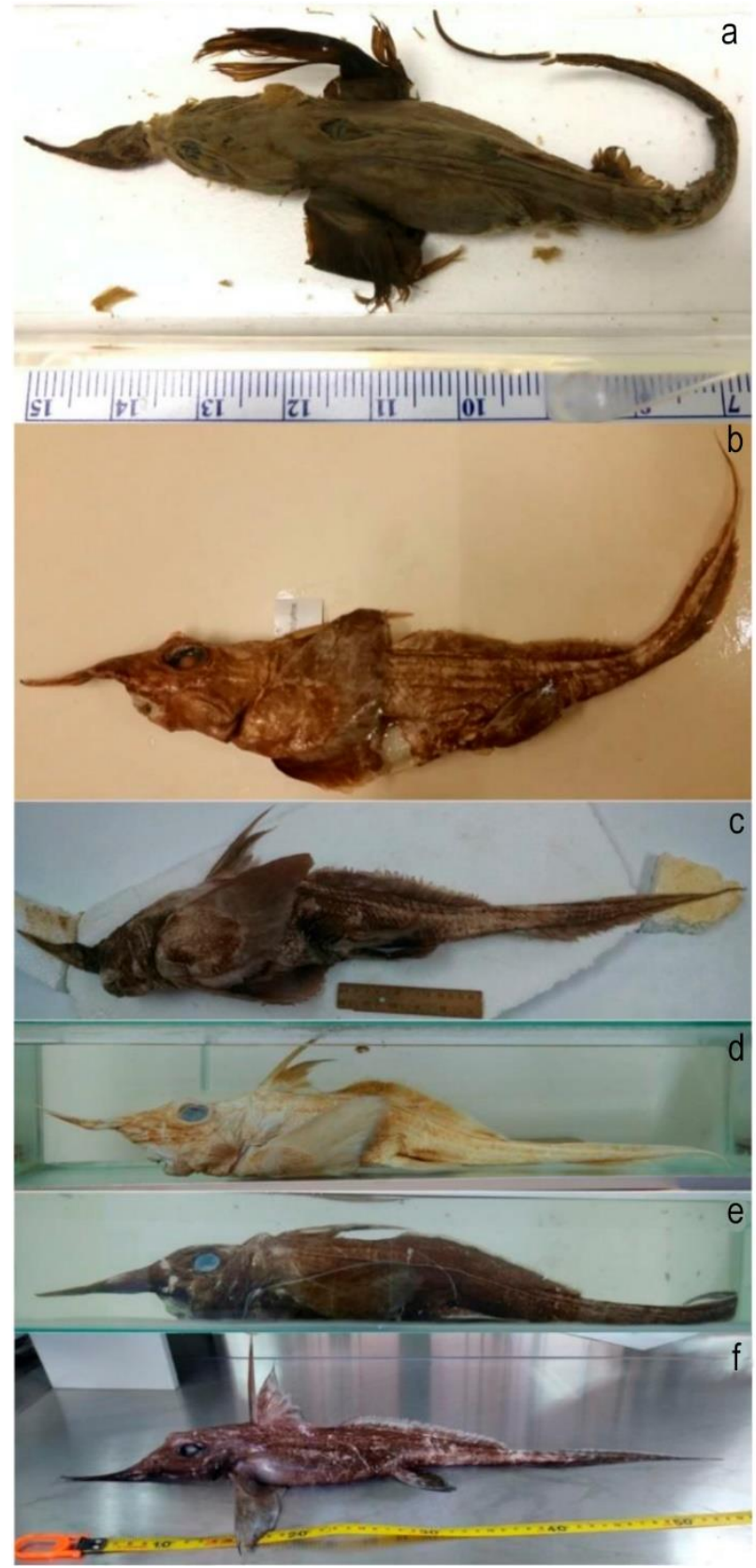

Figure 2. Harriotta raleighana. Specimens collected from the Mexican Pacific and deposited in scientific collections of Mexico and the USA. a) Townsend \& Nichols (1925), b) unpublished record, specimen deposited in the collection of the Ichthyology Section, Natural History Museum of Los Angeles County (LACM 38360-1), c) Castro-Aguirre et al. (2007), d) Medina-Rosas \& Raymundo-Huizar (2014), e) Medina-Rosas \& RaymundoHuizar (2019), f) Medina-Rosas \& Raymundo-Huizar (2020). Specimen of Van der Heiden (1985) is lost.

gion started more than 100 years ago, there is not enough information yet. Mexican territory in the ocean is more extensive than land; however, marine species' biological and ecological knowledge is insufficient.
There is an urgent need to study deep-sea organisms, not only chimaeras, to understand that particular but vast habitat, as well as determine its abundance, to resolve its real rareness. One issue to consider about this species, and other marine organisms, particularly from deep waters, is that they are found by fishermen, which sometimes graciously report them, and it is really difficult to study in their habitat.

As of today, in total, there are seven specimens of the chimaera $H$. raleighana deposited in scientific collections of Mexico and USA in almost 110 years (Table 1). Currently, four specimens are in Mexican institutions. The specimen from Colima is deposited in the Colección Ictiológica (CICIMAR-CI 6369) of the Centro Interdisciplinario de Ciencias Marinas, in La Paz, Baja California Sur; all three specimens collected in Jalisco are deposited in the Colección de Vertebrados del Centro de Estudios en Zoología (CZUG1041, CZUG1042, CZUG1043), from the Universidad de Guadalajara, and the Centro Universitario de la Costa (CUC), in Puerto Vallarta, Jalisco, Mexico, is the repository of these specimens, where they are under direct observation in crystal containers.

Unfortunately, the specimen collected in Sinaloa, in the Gulf of California in 1985, is missing from the Reference Collection of the Unidad Mazatlán of the Instituto de Ciencias del Mar y Limnología of the Universidad Nacional Autónoma de México. Several years ago, some fish specimens were transported to the Fish Reference Collection of the Centro de Investigación en Alimentación y Desarrollo in Mazatlán, Sinaloa, but not this particular chimaera specimen. This was confirmed by the collection responsible (Héctor Plascencia) and the report author (Albert Van der Heiden 1985) and can be validated in the online database of the collection (www.ciad.mx/colpeces).

Specimens of $H$. raleighana deposited in the USA institutions are in two different collections (Table 1). The adult specimen from Baja California collected in 1979 is in the Natural History Museum of Los Angeles County (LACM 38360-1) and the eggs (38513-1, 38514-1, 38515-1, and 38520-1). The specimen collected in 1911 is in the Museum Support Center of the Smithsonian Institution, in Suitland, Maryland.

Additionally, there are reports of specimens of this species observed but not collected in different documents: an identification fish guide of the Pacific of the USA (Eschmeyer et al. 1983); a guide of sharks and relatives with an image taken in the Gulf of California at $1553 \mathrm{~m}$ depth, with no information of the site (Didier et al. 2012); and a fish catalog, as a product of the expedition in deep waters in the Gulf of California, which only mentions that the species was observed in four different sites, with no other information nor coor- 
Table 1. Data of the seven specimens of Harriotta raleighana collected from the Mexican Pacific deposited in scientific collections of Mexico and the USA.

\begin{tabular}{|c|c|c|c|c|c|}
\hline Collection site & $\begin{array}{c}\text { Collection } \\
\text { date }\end{array}$ & $\begin{array}{l}\text { Collection (country) and catalog } \\
\text { number }\end{array}$ & $\begin{array}{l}\text { Total length } \\
(\mathrm{cm})\end{array}$ & Sex & Reference \\
\hline Baja California Sur & $22 / 04 / 1911$ & SI (USA) USNM 87552 & 15.2 & Not reported & Townsend \& Nichols (1925) \\
\hline Baja California & $30 / 04 / 1979$ & LACM (USA) 38360-1 & 69.8 & Not reported & Record not published \\
\hline Sinaloa & $24 / 03 / 1982$ & UNAM (Mex) 1981-1 (Missing) & 84.0 & Female & Van der Heiden (1985) \\
\hline Colima & $01 / 06 / 2006$ & CICIMAR (Mex) CI 6369 & 77.6 & Female & Castro-Aguirre et al (2007) \\
\hline Jalisco & $20 / 03 / 2014$ & CZUG (Mex) 1041 & 76.8 & Not reported & Medina-Rosas \& Raymundo-Huizar (2014) \\
\hline Jalisco & $18 / 01 / 2018$ & CZUG (Mex) 1042 & 85.5 & Female & Medina-Rosas \& Raymundo-Huizar (2019) \\
\hline Jalisco & $05 / 02 / 2020$ & CZUG (Mex) 1043 & 61.9 & Male & Medina-Rosas \& Raymundo-Huizar (2020) \\
\hline
\end{tabular}

dinates, by using a remotely operated underwater vehicle (Mejía-Mercado et al. 2013).

Regarding the total length of the specimens, the individual collected in Jalisco in 2018 is the longest $(85.5 \mathrm{~cm})$, and the one from Baja California Sur in 1991 is the shortest $(15 \mathrm{~cm})$. The total length of this species' specimens, except by one, is between 60 and $90 \mathrm{~cm}$ (Table 1), indicating their adult stage (Dagit et al. 2016). Compared to other records for this species in different regions of the world, Mexican specimens are longer than the ones from Costa Rica, where the maximum is $64 \mathrm{~cm}$ (Angulo et al. 2014), but shorter to the individuals from New Zealand, where adult specimens range from 77 to $97 \mathrm{~cm}$ (Garrick \& Inada 1975). Adult females of this species are more common in the North Atlantic's deeper habitats than males that are more common in shallower sites (Holt et al. 2013). Additionally, the first male was reported for the first time in more than a century (Medina-Rosas \& Raymundo-Huizar 2020) because only females or specimens with no sex have been reported (Table 1).

Remarkably, all specimens were found during the first half of the year, mainly during spring or winter, both seasons with three specimens captured each. Related to this, the observation and incidental captures of rare species from deep-sea waters in Mexico have increased in recent years, with records of other fish species, like the shortbill spearfish Tetrapturus angustirostris (De la Cruz-Agüero et al. 2019) and the oarfish Regalecus glesne (Medina-Rosas \& RaymundoHuizar 2019). Deepwater habitats are poorly studied and understood in Mexico. Therefore it is necessary to prevent activities that could potentially threaten these environments and their organisms (Dagit et al. 2016) and promote and increase the number of studies.

\section{CONCLUSIONS}

Harriotta raleighana is a chimaera species distributed in the Mexican Pacific, rarely observed. It has been collected only seven times in almost 100 years and is considered a rare species. It has been obtained from Baja California, Baja California Sur, Sinaloa, Jalisco, and Colima. Four specimens are deposited in scientific collections of Mexican institutions, and two more in the USA, as well as one missing specimen. Jalisco, in the south part of Bahia de Banderas, is the only Mexican site with three reports for this species. New records and collected specimens of this chimaera must be reported, deposited, and preserved adequately for future studies about Mexico's deep-sea waters' marine biodiversity.

\section{ACKNOWLEDGMENTS}

Thanks for the support during this work process to the staff of the different institutions where there are Mexican specimens or records of the Pacific longnose chimaera: Sergio Guerrero (Colección de Vertebrados, Centro de Estudios en Zoología, Universidad de Guadalajara); José de la Cruz Agüero and Víctor Manuel Cota (Colección Ictiológica del Centro Interdisciplinario de Ciencias Marinas, La Paz, Baja California Sur, Mexico); Héctor Plascencia (Colección del Centro de Investigación en Alimentación y Desarrollo, Mazatlán, Sinaloa, Mexico); Rick Feeney (Natural History Museum of Los Angeles County); Anna Omedes and Javier Quesada (Nat-Museo de Ciencias Naturales de Barcelona, Spain); Barbara Brown (American Museum of Natural History, New York, USA); Sandra Raredon (Smithsonian Institution, Maryland, USA). Thanks to Cassandra López for the map. We are grateful to the reviewers for comments on the manuscript.

\section{REFERENCES}

Ali, A., Jawad, L. \& Sheikh, A. 2009. First record of Neoharriotta pinnata (Condrichthys: Rhinochimaeridae) and second record of Satyrichthys adeni (Osteichthyes: Peristediidae) from Gulf of Aden, Republic of Yemen. Marine Biodiversity Records, 2: 1-4. doi: 10.1017/S1755267209990972

Angulo, A., López, M.I., Bussing, W.A. \& Murase, A. 2014. Records of chimaeroid fishes (Holocephali: 
Chimaeriformes) from the Pacific coast of Costa Rica, with the description of a new species of Chimaera (Chimaeridae) from the eastern Pacific Ocean. Zootaxa, 3861: 554-574. doi: 10.11646/zootaxa.3861. 6.3

Castro-Aguirre, J.L., Santana-Hernández, H., EspinoBarr, E. \& Jiménez-Quiroz, M.C. 2007. Primer registro de Harriota raleighiana (Chondrichthyes: Holocephali: Rhinochimaeridae) en la costa del Pacífico central de México. Revista Mexicana de Biodiversidad, 78: 489-492.

Dagit, D.D., Walls, R.H.L. \& Buscher, E. 2016. Harriotta raleighana. The IUCN Red List of Threatened Species 2016: e.T60140A3088899. doi: 10.2305/IUCN.UK. 2016-1.RLTS.T60140A3088899.en

De la Cruz-Agüero, J., González-Armas, R., GarcíaRodríguez, F.J. \& Cota-Gómez, V.M. 2019. First record of a specimen of the shortbill spearfish Tetrapturus angustirostris Tanaka, 1915 in the Pacific coast of Mexico. Latin American Journal of Aquatic Research, 47: 677-683. doi: 10.3856/vol47-issue4fulltext-9

De la Cruz-Agüero, J., García-Rodríguez, F.J., CotaGómez, V.M., Melo-Barrera, F.N. \& GonzálezArmas, R. 2012. Morphometric and molecular data on two mitochondrial genes of a newly discovered chimaeran fish (Hydrolagus melanophasma, Chondrichthyes). Ocean Science Journal, 47: 147-153.

Del Moral-Flores, L.F., Morrone, J.J., Alcocer, J. \& PérezPonce de León, G. 2016a. Diversidad y afinidades biogeográficas de los tiburones, rayas y quimeras (Chondrichthyes: Elasmobranchii, Holocephali) de México. Revista de Biología Tropical, 64: 1469-1486. doi: 10.15517/rbt.v64i4.22774

Del Moral-Flores, L.F., Morrone, J.J., Alcocer-Durand, J., Espinosa-Pérez, H. \& Pérez-Ponce de León, G. 2015. Lista patrón de los tiburones, rayas y quimeras (Chondrichthyes, Elasmobranchii, Holocephali) de México. Arxius de Miscel-lània Zoològica, 13: 47163. doi: $10.15470 / \mathrm{hrl} 1 \mathrm{kv}$

Del Moral-Flores, L.F, Morrone J.J., Alcocer-Durand, J., Espinosa-Pérez, H. \& Pérez-Ponce de León, G. 2016b. Listado anotado de los tiburones, rayas y quimeras (Chondrichthyes, Elasmobranchii, Holocephali) de México. Natural History Museum of Barcelona, Barcelona. doi: 10.15470/hrl1kv

Del Moral-Flores, L.F., Ramírez-Villalobos, A.J., Martínez-Pérez, J.A., González-Acosta, A.F. \& Franco-López, J. 2018. Colecciones ictiológicas de Latinoamérica. Universidad Nacional Autónoma de México, Ciudad de México.

Didier, D.A., Kemper, J.M. \& Ebert, D.A. 2012. Phylogeny, biology, and classification of extant holocephalans. In: Carrier, J.C., Musick, J.A. \&
Heithaus, M.R. (Eds.). Biology of sharks and their relatives. CRC Press, Boca Raton, pp. 97-122.

Ebert, D.A. \& Stehmann, M.F.W. 2013. Sharks, batoids, and chimaeras of the North Atlantic. FAO species catalogue for fisheries purposes, 7, FAO, Rome, 523 pp.

Eschmeyer, W.N., Herald, E.S. \& Hammann, H. 1983. A field guide to Pacific coast fishes North America. Houghton Mifflin Company, New York.

Espinosa, H. 2003. La colección nacional de peces, métodos y usos. TIP Revista Especializada en Ciencias Químico-Biológicas, 6: 30-36.

Espinosa-Pérez, H. 2014. Biodiversidad de peces en México. Revista Mexicana de Biodiversidad, 85: 450459.

Finucci, B., Dunn, M.R., Jones, E.G. \& Anderson, J. 2017. Reproductive biology of the two deep-sea chimaerids, longnose spookfish (Harriotta raleighana) and Pacific spookfish (Rhinochimaera pacifica). Deep-Sea Research Part I: Oceanographic Research Papers, 120: 76-87. doi: 10.1016/ j.dsr.2016.11.008

Froese, R. \& Pauly, D. (Eds.). 2019. FishBase. World Wide Web electronic publication. [http://www.fishbase.org]. Reviewed: October 2, 2020.

Garrick, J.A.F. \& Inada, T. 1975. Dimensions of longnosed chimaera Harriotta raleighana from New Zealand. New Zealand Journal of Marine and Freshwater Research, 9: 159-167. doi: 10.1080/ 00288330.1975 .9515556

Global Biodiversity Information Facility (GBIF) in 2020. World Wide Web electronic publication [https://www. gbif.org]. Reviewed: October 2, 2020.

Goode, G.B. \& Bean, T.H. 1895. On Harriotta, a new type of chimaeroid fish from the deeper waters of the northwestern Atlantic. In: Scientific results of exploration by the U.S. Fish Commission Steamer Albatross. Proceedings of the United States National Museum, 17: 471-473.

Holt, R.E., Foggo, A., Neat, F.C. \& Howell, K.L. 2013. Distribution patterns and sexual segregation in chimaeras: implications for conservation and management. ICES Journal of Marine Science, 70: 1198-1205. doi: 10.1093/icesjms/fst058

Karrer, C. 1972. Die Gattung Harriotta Goode and Bean, 1895 (Chrondrichthyes, Chimaeriformes, Rhinochimaeridae). Mit Beschreibung einer neuen Art aus dem Nordatlantik. Mitteilungen aus dem Zoologischen Museum in Berlin, 48: 203-221.

Kemp, C. 2015. The endangered dead. Nature, 518: 292294. doi: $10.1038 / 518292$ a

Medina-Rosas, P. \& Raymundo-Huizar, A.R. 2014. Primer registro del pez de aguas profundas Harriotta raleighana (Chondrichthyes: Rhinochimaeridae) en la costa de Jalisco, Pacífico Mexicano. Revista Mexicana de Biodiversidad, 85: 1277-1281. 
Medina-Rosas, P. \& Raymundo-Huizar, A.R. 2019. Segundo reporte de la quimera Harriotta raleighana (Chondrichthyes: Rhinochimaeridae) en Bahía de Banderas, Jalisco. Hidrobiológica, 29: 89-92.

Medina-Rosas, P. \& Raymundo-Huizar, A.R. 2020. Primer registro de un macho de la quimera Harriotta raleighana (Chondrichthyes: Holocephali: Rhinochimaeridae) en el Pacífico Mexicano. Acta Pesquera, 11: 34-39.

Mejía-Mercado, B.E., Balart-Páez, E., Sosa-Nishizaki, O. \& Hinojosa-Corona, A. 2013. Catálogo fotoidentificación de la fauna íctica de profundidad (3503800 m) del Golfo de California, México. CICESE/ CIBNOR, Ensenada.

Møller, P.R., Nielsen, J.G., Knudsen, S.W., Poulsen, J.Y., Sünksen, K. \& Jørgensen, O.A. 2010. A checklist of the fish fauna of Greenland waters. Zootaxa, 2378: 184.

Nelson, J.S., Grande, T.C. \& Wilson, M.V.H. 2016. Fishes of the world. John Wiley \& Sons, New Jersey.

Ocean Biogeographic Information System (OBIS). 2020. World Wide Web electronic publication. [https:// www.obis.org]. Reviewed: October 2, 2020.

Priede, I.G. 2017. Deep-sea fishes. Biology, diversity, ecology and fisheries. Cambridge University Press, Cambridge.

Roberts, C.D., Stewart, A.L. \& Struthers, C.D. 2015. The fishes of New Zealand. Te Papa Press, Wellington.

Received: April 7, 2020; Accepted: October 19, 2020
Robertson, D.R. \& Allen, G.R. 2015. Shorefishes of the tropical eastern Pacific: online information system. Version 2.0. Smithsonian Tropical Research Institute, Balboa. [https://biogeodb.stri.si.edu/sftep/en/thefishes/ species/5261]. Reviewed: March 20, 2020.

Shuresh, T.V. \& Raffi, S.M. 2012. First record of long nose chimaera Neoharriotta pinnata (Chondrichthyes: Chimaeriformes: Rhinochimaeridae), from Bay of Bengal, India (northeastern Indian Ocean). Marine Biodiversity Records, 5: 1-3. doi: 10.1017/S175526 7212000115

Townsend, C.H. \& Nichols, J.T. 1925. Deep-sea fishes of the 'Albatross' Lower California Expedition. Bulletin of American Museum of Natural History, 52: 1-20.

Van der Heiden, A. 1985. Additional morphometric data on Harriotta raleighana (Holocephali: Rhinochimaeridae) and description of copulation marks. Revista de Biología Tropical, 33: 185-187.

Weigmann, S. 2016. Annotated checklist of the living sharks, batoids and chimaeras (Chondrichthyes) of the world, with a focus on biogeographical diversity. Journal of Fish Biology, 88: 837-1037.

World Register of Marine Species (WoRMS). 2020. World Register of Marine Species. [http://www.marinespecies.org]. Reviewed: October 2, 2020. 